\title{
Synthesis of 1,2-Amino Alcohols via Asymmetric Hydrogenation
}

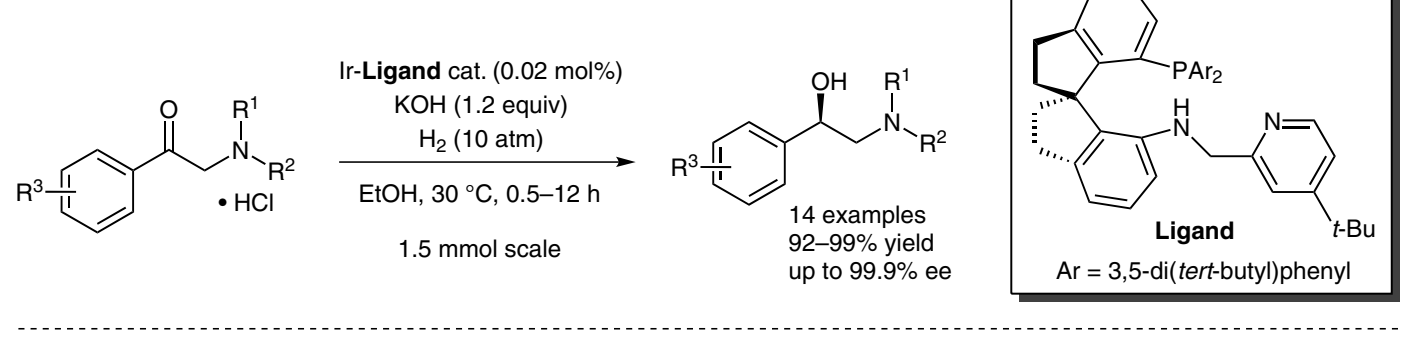

Selected examples:<smiles>CN(Cc1ccccc1)CC(O)c1ccccc1</smiles><smiles>COc1ccc(C(O)CN(C)Cc2ccccc2)cc1</smiles><smiles>CN(Cc1ccccc1)CC(O)c1ccc(Cl)cc1</smiles><smiles>Cc1cccc(C(O)CN(C)Cc2ccccc2)c1</smiles><smiles>COc1ccccc1C(O)CN(C)Cc1ccccc1</smiles><smiles>O=[N+]([O-])Cc1ccccc1</smiles><smiles>CCCN(Cc1ccccc1)CC(O)c1ccccc1Cl</smiles><smiles>CC(C)(C)NCC(O)c1ccccc1</smiles>

Gram-scale synthesis of $(R)$-phenylephrine hydrochloride:<smiles>CN(CC(=O)c1cccc(O)c1)Cc1ccccc1</smiles>

Ir-Ligand cat. (0.001 mol\%)

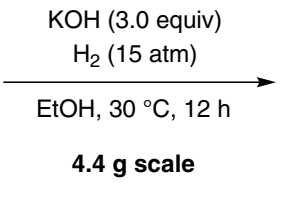<smiles>CN(Cc1ccccc1)CC(O)c1cccc(O)c1</smiles>

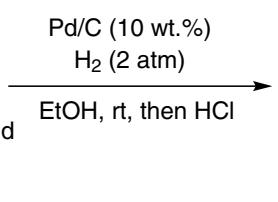<smiles>CNCC(O)c1cccc(O)c1</smiles>

Significance: Chiral 1,2-amino alcohols are very commonly found in pharmaceuticals and natural products. Although many methods exist for their synthesis, the present one, based on asymmetric hydrogenation, is notable for its efficiency in terms of enantioselectivity and turnover number (up to 100 000).
Comment: Excellent yields and enantioselectivities were obtained on a range of aromatic $\alpha$-amino ketones with a low catalyst loading (0.02 mol\%). When an alkyl $\alpha$-amino ketone was employed, the product was formed in $98 \%$ yield, but was nearly racemic. The authors demonstrate the utility and scalability of their method with the synthesis of $(R)$-phenylephrine hydrochloride, using only 0.001 mol\% catalyst $(\mathrm{TON}=100$ 000). 